\title{
The Impact of Sustainable Tourism and Good Governance on Biodiversity Loss in Malaysia
}

\author{
Badariah Din ${ }^{1}$, Muzafar Shah Habibullah ${ }^{2}$, W.C. Choo ${ }^{3}$ \\ ${ }^{1}$ College of Law, Government and International Studies, Universiti Utara Malaysia, 06010 UUM \\ Sintok, Kedah, Malaysia \\ ${ }^{2,3}$ Faculty of Economics and Management, Universiti Putra Malaysia, 43400 UPM Serdang, Selangor, \\ Malaysia
}

\begin{abstract}
The importance of forest in providing the natural habitat for plants and animals; storing hundreds of billions of tons of carbon; buffering against flood and drought; stabilizing soils, influencing climate change and providing food and home for the indigenous people has led the international community to protect them from further destruction in the future. In addition, the sustainable tourism is a key source of income and employment for local communities, which, in turn, provide strong incentives to protect biodiversity. For such reasons, and given the capacity limits of environmental resources coupled with the quantitative growth of tourism, there is an urgent need for the development of tourism to take biodiversity seriously. In this study we investigate the impact of sustainable tourism and good governance indicators on biodiversity loss in Malaysia for the period 1996 to 2012. In this study we employed the Ordinary Least Squares (OLS), Dynamic OLS (DOLS) and Fully-Modified OLS (FMOLS) which is efficient in small sample to estimate the long-run model of biodiversity loss (proxy by deforestation rates). Interestingly, our results found that good governance and sustainable tourism do contribute in mitigating biodiversity loss in Malaysia.
\end{abstract}

\section{Introduction}

Malaysia is one of the fastest growing economy among the ASEAN countries where the manufacturing sector being the main driver for economic growth. For the last two decades the tourism sector has been showing significant contribution to the Malaysian gross domestic product. As shown in Table 1, the share of the tourism industry to total national output hovering about 5 percent for the period $2005-2012$. Another important contribution of the tourism sector is in terms of job opportunities it created for the Malaysian population. In 2012, the share of employment in the tourism industry to total employment in Malaysia is about 16.4 percent showing an almost 10 percent increase from its share in 2005. Table 1 also suggests that the demand for tourism in Malaysia is increasing over time. Tourist arrivals increased from 16,431 thousands in 2005 to 25,032 thousands in 2012 and tourist expenditures has doubled from RM32 billion in 2005 to RM61 billion in 2012. Furthermore, the length of stay by the visitors has also increased from 6.1 nights in 2005 to 7 nights in 2012. 
Table 1. Some statistics on tourism in Malaysia

\begin{tabular}{|c|c|c|c|c|c|c|c|c|}
\hline Year & $\begin{array}{l}\text { Tourist } \\
\text { Arrivals } \\
\text { ('000) }\end{array}$ & $\begin{array}{l}\text { Tourist } \\
\text { Receipts } \\
\text { (RM } \\
\text { Million) }\end{array}$ & $\begin{array}{l}\text { Average } \\
\text { Length } \\
\text { of stay } \\
\text { (Nights) }\end{array}$ & $\begin{array}{l}\text { No. of } \\
\text { hotels } \\
\text { supply }\end{array}$ & $\begin{array}{l}\text { No. of } \\
\text { rooms } \\
\text { supply }\end{array}$ & $\begin{array}{l}\text { Average } \\
\text { occupancy } \\
\text { rates of } \\
\text { hotels } \\
(\%)\end{array}$ & $\begin{array}{l}\text { Share of } \\
\text { employment } \\
\text { in the } \\
\text { tourism } \\
\text { industries to } \\
\text { total } \\
\text { employment } \\
\text { (\%) }\end{array}$ & $\begin{array}{l}\text { Share of } \\
\text { tourism } \\
\text { sector to } \\
\text { gross } \\
\text { domestic } \\
\text { product } \\
(\%)\end{array}$ \\
\hline 2005 & $16,431.1$ & $31,954.1$ & 6.1 & 2,269 & 155,356 & 63.6 & 15.0 & 4.7 \\
\hline 2006 & $17,546.9$ & $36,271.7$ & 6.2 & 2,336 & 157,251 & 65.5 & 15.1 & 4.7 \\
\hline 2007 & $20,972.8$ & $46,070.0$ & 6.3 & 2,360 & 160,327 & 70.0 & 14.9 & 4.9 \\
\hline 2008 & $22,052.5$ & $49,561.2$ & 6.4 & 2,373 & 165,739 & 66.3 & 15.7 & 4.9 \\
\hline 2009 & $23,646.2$ & $53,367.7$ & 6.7 & 2,373 & 168,844 & 60.9 & 16.1 & 5.4 \\
\hline 2010 & $24,557.2$ & $56,492.5$ & 6.8 & 2,367 & 168,497 & 59.3 & 15.5 & 5.3 \\
\hline 2011 & $24,714.3$ & $58,315.9$ & 7.0 & 2,707 & 193,340 & 60.6 & 16.2 & 5.2 \\
\hline 2012 & $25,032.7$ & $60,556.7$ & 7.0 & 2,724 & 195,445 & 62.4 & 16.4 & 5.3 \\
\hline
\end{tabular}

Sources: Department of Statistics, Tourism Satellite Account, Malaysia, 2005-2012.

Although we recognized the great benefits of the tourism sector to the national income, the tourism activities has also been connected to the negative impact on the economy in particular to the environment. One crucial aspect of the negative impact as a result of increase tourism activities is on the loss of biodiversity. The term biodiversity or biological diversity refers to the totality (numbers) and variability (types) of living organisms in the ecosystem, region and environment [1]. Human will eventually perish without biodiversity. According to the Convention on Biological Diversity (CBD) the definition of biodiversity includes diversity at the gene, species and ecosystem levels; the types of species; and the habitats and ecosystems within which they live. This includes the terrestrial rainforests, the freshwater lakes, the river systems, the coral reefs and the marine ecosystems. The healthy ecosystems provide food, clean air and water for human to consume and survive. The rainforest, although cover less than 2 percent of Earth's surface, support the greatest diversity of living organisms on Earth - housed more than 50 percent of the plants and animals on the planet [2]. Therefore, the loss of biodiversity among other things; threatens our food supplies, interferes with essential ecological functions, reduces the productivity of ecosystems, and destabilizes and expose the vulnerability of the ecosystems to natural disasters such as floods, droughts, hurricanes etc [3].

In a study led by the Conservation International (CI) and United Nations Environment Programme (UNEP) on the threats of tourism on biodiversity conservation [4] point out that the tourism-related for loss of biodiversity can be due to: (i) habitat disruption due to the total landscape transformation for tourism development (infrastructure and facilities) in a rapid and unplanned manner that led to deforestation and drainage of wetlands; (ii) depletion of scarce resources for the indigenous and local people (e.g. water and electricity consumption); (iii) problems associated with littering and water pollution; (iv) sewage pollution from hotels, recreation and other tourism-related facilities; and (v) damage to coral reefs by the activities of careless tourists. Nevertheless, according to [5] tourism can be an incentive for the protection of the environment. For example, tourism tends to create an awareness that the country needs to be attractive, air needs to be cleaned, and sea needs to be unpolluted. In the long-run, without appropriate policies and incentives to mitigate the negative impact of tourism activities on the environment, tourism can destroy itself. For the last two decades, national policies for tourism have been targeted for achieving economic growth and social development while protecting the environmental aspect of a country [6]. Relating to the concept of "sustainable tourism", [7] urges nations to make optimal use of environmental resources for tourism development while maintaining essential ecological processes and helping to conserve natural 
heritage and biodiversity [8]. [9] for example defines sustainable tourism as "tourism which is developed and maintained in such a manner and scale that it remains viable in the long-run and does not degrade the environment in which it exists to such an extent that it prohibits the successful development of other activities."

Thus, the purpose of the present study is to investigate the impact of sustainable tourism on biodiversity loss in Malaysia for the period 1996 - 2012. We also include income and measures of good governance as additional determinants of biodiversity loss, and the model is estimated using three estimators - ordinary least squares (OLS), dynamic OLS (DOLS) and fully-modified OLS (FMOLS). Both DOLS and FMOLS are efficient in small sample.

The paper is organized as follows. In the next section we review briefly the empirical work related to biodiversity loss, sustainable tourism and good governance as well as the method used in the study. In section 3, we discuss the empirical results. The last section contains our conclusions.

\section{Methodology}

In this study, we modeled biodiversity loss as follows:

$$
\text { biodiversityloss }=f \text { (income, sustainable tourism, governace) }
$$

Specify in a stochastic form as

$$
\text { BioLoss }_{\mathrm{t}}=\boldsymbol{a}+\text { Bincome }_{\mathrm{t}}+\text { Esus_tourism }_{\mathrm{t}}+\gamma \text { govern }_{\mathrm{t}}+\varepsilon_{\mathrm{t}}
$$

where $\alpha, \beta, \theta$, and $\gamma$ are parameters to be estimated, and $\varepsilon$ is the error term. It is expected that $\beta>0$, and $\theta, y<0$. BioLoss $s_{t}$ is the loss of biodiversity that will be measured by deforestation rates. income $_{t}$ represent the level of economic development and/or national income and is measured by gross domestic product. sus_tourism $m_{\mathrm{t}}$ is sustainable tourism and will be measured by constructing an index for sustainable tourism indicator, while govern $t$ represent institutional variables that measure the quality of the government.

The increase in the level of economic development or national income increases the loss of biodiversity as a result of deforestation that give way for agriculture, infrastructure and buildings etc. For example [10] found that income (GDP) affect positively the rate of deforestation for a panel of the African, Latin American and the Asian countries. [11] on the other hand, the African and Latin American show positive relationship between deforestation and income, but for the Asian countries, income and deforestation is negatively related.

In recent years several studies has been investigating the role of governance affecting biodiversity loss and deforestation. It has been recognized that better institutions are related to better environmental management, forward-looking behaviors, higher efficiency and better enforcement of public policies. Thus, it can be conclude that better institutions are related to lower deforestation. More recently [12-13] explore the hypothesis that improving good governance is able to mitigate deforestation. In their study, six governance measures - voice and accountability, political stability, government effectiveness, regulatory quality, rule of law and control of corruption were used which was based on the database - World Governance Indicators provided by the World Bank. The indicators were constructed by Kaufman and his colleagues based on several different sources and using the linear unobserved components model to aggregate those various sources into one aggregate indicator. [14] define governance as, "Governance consists of the traditions and institutions by which 
authority in a country is exercised. This includes the process by which governments are selected, monitored and replaced; the capacity of the government to effectively formulate and implement sound policies; and the respect of citizens and the state for the institutions that govern economic and social interactions among them." Accordingly, the six governance measures taken from the World Bank (see info.worldbank.org/governance/wgi/index.asp) are as follows:

- Voice and accountability: measures perceptions of the extent to which a country's citizens are able to participate in selecting their government, as well as freedom of expression, freedom of association, and a free media.

- Political stability and absence of violence: measures perceptions of the likelihood that the government will be destabilized or overthrown by unconstitutional or violent means, including politically-motivated violence and terrorism.

- Government effectiveness: measures perceptions of the quality of public services, the quality of the civil service and the degree of its independence from political pressures, the quality of policy formulation and implementation, and the credibility of the government's commitment to such policies.

- Regulatory quality: measures perceptions of the ability of the government to formulate and implement sound policies and regulations that permit and promote private sector development.

- Rule of law: measures perceptions of the extent to which agents have confidence in and abide by the rules of society, and in particular the quality of contract enforcement, property rights, the police, and the courts, as well as the likelihood of crime and violence.

- Control of corruption: measures perceptions of the extent to which public power is exercised for private gain, including both petty and grand forms of corruption, as well as "capture" of the state by elites and private interests.

[12] investigate the relationship between deforestation and six governance indicators for a crosssection of 90 countries. However, they conclude that the evidence do not support a direct beneficial of good governance on deforestation but an indirect of governance on deforestation through increasing income. They suggest that good governance may act a catalyst to increasing income, and rising income are likely to reduce the rate of deforestation. According to [12], "the lack of support for a direct impact of governance variables on deforestation is consistent with the notion that governance is a macro-level variable, and as such its impact on the forestry sector a priori is expected to be diffuse and uncertain."

On the other hand [13] tested the impact of good governance on deforestation for 120 countries. The correlation analyses clearly indicate a negative relationship between the rate of deforestation and the governance indicators. It implies that globally a country with a better quality of governance tends to have a lower rate of deforestation. Further analysis with multiple regression analysis, their results support the contention that an increase in the quality of governance corresponds to a lower level of deforestation.

The tourism industry is no doubt beneficial to the nation providing job opportunities, foreign exchange earnings and infrastructure development that is related as well non-related tourism activities. Nevertheless, the rapid growth in the tourism industry has been recognized of being responsible for a considerable negative local community and environmental impact. The natural resource depletion and environmental degradation that is associated with tourism activities pose severe problems to many regions favored by tourists [15]. Tourism development negatively impacted the community in term of traffic congestion, increase cost of living, crime rates, waste water generation, pollution etc [16]. Therefore, recent strategies for tourism development are to maximize the economic benefits to the local community while minimizing the environmental and social costs [17]. Implying "sustainable tourism development", [18] promotes "tourism that takes full account of its current and future economic, social and environmental impacts, addressing the needs of visitors, the industry, the environment and host communities." Nevertheless, [19-20] and [21] point out that sustainable tourism as a concept is meaningless without indicators that can measure the impact of tourism. According to [7, 22-23] sustainable tourism indicators are time series information that is 
expected to respond to economic, social, cultural, environmental, institutional, technological, management issues, both within and tourism sector and broader destination.

To construct an index for sustainable tourism for Malaysia, we have selected three sustainability indicator variables - ratio of tourism expenditures to GDP (tourismy) [8, 24], ratio of tourist arrival to population (touristpop) [8, 25] and rainfall (rain) [26]. Both tourismy and touristpop can be considered as the driving forces indicators representing the social dimension, while rain can be considered as the pressure indicators representing the environment dimension [21, 26]. Following [26], by using factor analysis, we select the first principal component and by normalizing the sum of the loading factor equal to one, we have the following sustainable tourism index (sus_tourism) for Malaysia:

sus_tourism $_{\mathrm{t}}=0.336$ tourism $y_{\mathrm{t}}+0.392$ tourist pop $p_{\mathrm{t}}+0.272$ rain $_{\mathrm{t}}$

We would expect that an increase in sustainable tourism will reduced the loss of biodiversity.

\section{Results and discussions}

In this study our main interest is to investigate the impact of sustainable tourism and good governance on biodiversity loss in Malaysia. We hypothesis that better governance will lead to lower rate of deforestation and this will also implies that good governance mitigate biodiversity loss in Malaysia. The adoption of sustainable tourism practices will also expected to reduce biodiversity loss. Following [27], in this study, the deforestation rate (proxy for biodiversity loss) was calculated as the ratio of change in forest area using data from United Nation Food and Agriculture Organization for the period 1996 to 2012. For the governance indicators, we used all six measures of governance - voice and accountability, political stability, government effectiveness, regulatory quality, rule of law, and control of corruption. All these variables are taken from the World Bank Governance Indicators constructed and compiled by the World Bank. On the other hand, data for GDP and tourism related are taken for World Development Indicators (WDI) download for the World Bank database. In this study all variables are transformed into natural logarithm except the governance indicators.

Estimating Equation (2) using Ordinary Least Square (OLS) is not without problems. The parameter estimates can be biased in small samples as well as in the presence of dynamic effects, and this bias varies inversely with the size of the sample and the calculated $R^{2}$. According to [28] estimating Equation (1) is subject to the so-called spurious regression results as the equation contains non-stationary economic variables. Furthermore, there is the problem caused by the likely endogeneity of the regressors which would prevent OLS estimating the true values of the parameters.

These problems associated with the OLS approach have led to the development of alternative procedures which is more recent and more robust, particularly in small samples. [29] propose the dynamic OLS (DOLS) while Phillips and Hansen [30] propose the fully-modified OLS (FMOLS). DOLS procedure corrects for possible simultaneity bias and small sample bias amongst the regressors by regressing one of the $I(1)$ variables on other $I(1)$ variables, the $I(0)$ variables, and lags and leads of the first difference of the $I(1)$ variables. Incorporating the first difference variables and the associated lags and leads will eliminates simultaneity bias and small sample bias inherent among regressors. On the other hand, the FMOLS procedure correct for endogeneity and serial correlation effects as well as eliminates the small sample bias. The FMOLS needs two conditions to be fulfilled. First, there needs to be only one cointegrating vector. Second, the explanatory variables should not be cointegrated among themselves [31]. 
As usual when dealing with time series economic variables, we test for the order of integration of the series involved for future analysis. In this study we employed the traditional Augmented DickeyFuller (ADF) unit root test popularized by [32], by testing the series in levels and then in their first differences. The results for the test for the order of integration are presented in Table 2. As shown in Table 2, we can safely conclude that all the series are said to be of the order one, that is, they are I(1) variables. In other words these economic variables are said to achieve stationarity after differencing once. As shown in Table 2, all series in first differences are statistically significant at least at the 10 percent level (the critical values are provided by [33]).

Table 2. Results of unit root tests for biodiversity loss, income, sustainable tourism and governance indicators

\begin{tabular}{lll}
\hline Variables & ADF unit root tests: & \\
\cline { 2 - 3 } & Levels & First-differences \\
\hline Biodiversity & $-1.73(1)$ & $-3.06^{*}(0)$ \\
Income & $-1.96(0)$ & $-3.71^{* *}(0)$ \\
Sus_Tourism & $-2.90(0)$ & $-3.81^{* *}(0)$ \\
Voice and accountability & $-2.93(1)$ & $-3.57^{* *}(1)$ \\
Political stability & $-1.95(1)$ & $-3.37^{* *}(1)$ \\
Government effectiveness & $-1.07(1)$ & $-4.09^{* * *}(0)$ \\
Regulatory quality & $-3.00(1)$ & $-3.46^{* *}(1)$ \\
Rule of law & $-2.95(1)$ & $-2.76^{*}(1)$ \\
Control of corruption & $-2.09(1)$ & $-3.78^{* *}(0)$ \\
& & \\
\hline
\end{tabular}

Notes: Asterisks ***,**, * denote statistically significance at the $1 \%, 5 \%$ and $10 \%$ level respectively. Critical values are taken from [33]. Series in levels were estimated with constant and trend, while series in firstdifferences were estimated with constant only. Figures in parentheses denote lag length.

For completeness we report the regression estimates using OLS in Table 3 as a guide. As shown in Table 3, in most of the cases income and sustainable tourism are significant and show correct signs. The governance indicators are significant only for political stability and rule of law. Nevertheless, we are cautious of these results as they are spurious.

Table 4 presents the results of estimating equation (2) using DOLS. To check for spurious regression we test for cointegration using Hansen [34] instability test. According to [34], the $L_{c}$ statistics is an $L M$ test statistic and can be used to test for the null of cointegration against the alternative of no cointegration. The $L_{c}$ statistics at the bottom row in Table 4 clearly suggest that the variables are cointgerated and therefore the DOLS regression estimates are non-spurious. Income is significant and positively related with biodiversity loss in equations with voice and accountability, regulatory quality and control of corruption. Similarly, in these three equations, sustainable tourism indices clearly suggest that increase in sustainable tourism reduce biodiversity loss. On the other hand, the three governance indicators - voice and accountability, regulatory quality and control of corruption are significant and negatively related with biodiversity loss, implying that good governance can mitigate the loss of biodiversity in Malaysia. 
Table 3. OLS results of the impact of income, sustainable tourism and good governance on biodiversity loss

\begin{tabular}{lllllll}
\hline Variables & $\begin{array}{l}\text { Voice \& } \\
\text { Accountability }\end{array}$ & $\begin{array}{l}\text { Political } \\
\text { stability }\end{array}$ & $\begin{array}{l}\text { Government } \\
\text { effectiveness }\end{array}$ & $\begin{array}{l}\text { Regulatory } \\
\text { quality }\end{array}$ & Rule of law & $\begin{array}{l}\text { Control of } \\
\text { corruption }\end{array}$ \\
\hline \multirow{2}{*}{ constant } & $0.6844^{* * *}$ & $0.6867^{* * *}$ & $0.6853^{* * *}$ & $0.6856^{* * *}$ & $0.6827^{* * *}$ & $0.6864^{* * *}$ \\
& $(187.37)$ & $(270.51)$ & $(188.36)$ & $(198.82)$ & $(250.64)$ & $(134.61)$ \\
income $_{\mathrm{t}}$ & $0.0020^{* *}$ & $0.0015^{* *}$ & 0.0014 & $0.0024^{* * *}$ & $0.0024^{* * *}$ & $0.0019^{* *}$ \\
& $(2.5131)$ & $(2.9394)$ & $(1.7655)$ & $(3.0781)$ & $(4.1858)$ & $(2.5053)$ \\
sus_tourism $_{1}$ & $-0.0032^{* *}$ & $-0.0025^{* * *}$ & -0.0016 & $-0.0038^{* * *}$ & $-0.0031^{* * *}$ & $-0.0034^{*}$ \\
& $(2.3182)$ & $(3.1733)$ & $(1.0324)$ & $(3.0470)$ & $(3.6372)$ & $(2.0634)$ \\
govern & -0.0008 & $-0.0019^{* * *}$ & -0.0015 & -0.0028 & $-0.0043^{* * *}$ & -0.0009 \\
& $(0.6106)$ & $(4.0203)$ & $(1.0956)$ & $(1.6273)$ & $(3.4424)$ & $(0.5652)$ \\
$R$-squared & & & & & & \\
SER & 0.337 & 0.696 & 0.376 & 0.433 & 0.643 & 0.334 \\
& 0.0005 & 0.0003 & 0.0005 & 0.0005 & 0.0004 & 0.0005
\end{tabular}

Notes: Asterisks ***,**,* denote statistically significant at the $1 \%, 5 \%$ and $10 \%$ level respectively. Figures in the parentheses are $t$-statistics. SER denotes standard error of regression.

Table 4. DOLS results of the impact of income, sustainable tourism and good governance on biodiversity loss

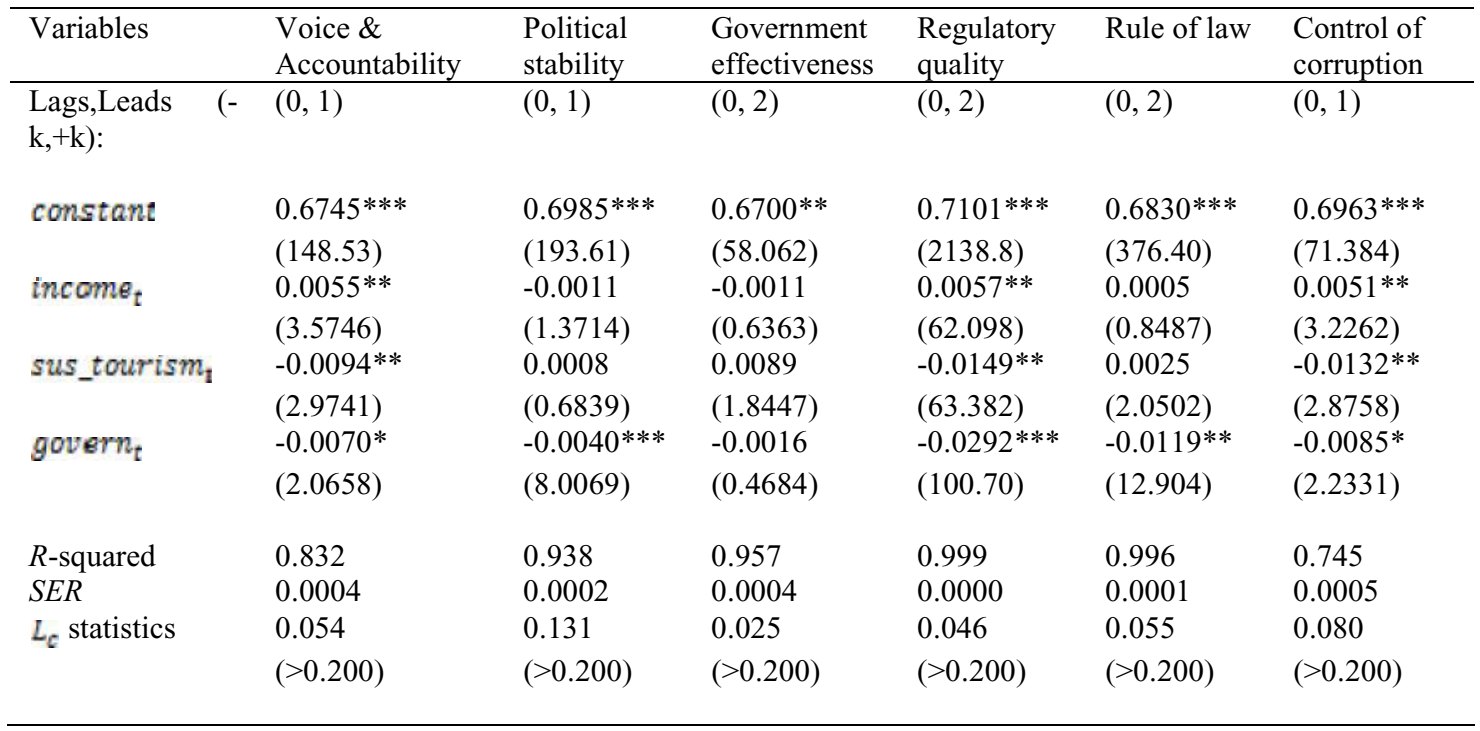

Notes: Asterisks ***, **, * denote statistically significant at the $1 \%, 5 \%$ and $10 \%$ level respectively. Figures in the parentheses are t-statistics. Critical values for $L_{c}$ statistics are given in [34]. SER denotes standard error of regression.

Estimates for the FMOLS procedure is shown in Table 5. Results in Table 5 show that the $L_{c}$ statistics clearly cannot reject the null of cointegration in all six equations estimated. Income is positive and statistically significantly different from zero at least at the 5 percent level. Sustainable tourism is statistically significantly different from zero at least at the 10 percent level and show negative sign - increase sustainable tourism reduce biodiversity loss. However, only political stability, regulatory quality and rule of law are statistically significantly different from zero at least 
at the 10 percent and show correct sign. Nevertheless, in general, the above results clearly suggest that sustainable tourism and good governance will result in lower deforestation rates and therefore help in reducing the loss in biodiversity in Malaysia.

\section{Conclusion}

The tourism sector is economically important because it is a source of foreign exchange, as well as job opportunities for the masses. Recent approach for tourism development is to balance between harvesting the benefits from tourism activities without degrading the environment and create unfails opportunities for the local communities. Policies targeted for sustainable tourism with the hope that boosting the tourism industry at the same time be able to mitigate the loss of biodiversity resulted from tourism activities. Nevertheless, a key element in the potential success of a country's development policies is dependent on the quality of the government or the practice of good governance.

In this study we investigate whether sustainable tourism and good governance practices by the government of Malaysia has any positive impact in reducing the rate of deforestation for the period 1996 to 2012.In this study we used a macro-level measures of governance indicators provided by the world bank - voice and accountability, political stability and absence of violence, government effectiveness, regulatory quality, rule of law, and control of corruption. Sustainable tourism was constructed as an index using three sustainability indicators - ratio of tourism expenditures to GDP, ratio of tourist arrival to population, and rainfall.

Table 5. FMOLS results of the impact of income, sustainable tourism and good governance on biodiversity loss

\begin{tabular}{|c|c|c|c|c|c|c|}
\hline Variables & $\begin{array}{l}\text { Voice \& } \\
\text { Accountability }\end{array}$ & $\begin{array}{l}\text { Political } \\
\text { stability }\end{array}$ & $\begin{array}{l}\text { Government } \\
\text { effectiveness }\end{array}$ & $\begin{array}{l}\text { Regulatory } \\
\text { quality }\end{array}$ & Rule of law & $\begin{array}{l}\text { Control of } \\
\text { corruption }\end{array}$ \\
\hline constant & $\begin{array}{l}0.6798^{* * *} \\
(165.83)\end{array}$ & $\begin{array}{l}0.6863 * * * \\
(279.92)\end{array}$ & $\begin{array}{l}0.6831^{* * *} \\
(187.63)\end{array}$ & $\begin{array}{l}0.6824 * * * \\
(179.43)\end{array}$ & $\begin{array}{l}0.6815^{* * *} \\
(316.77)\end{array}$ & $\begin{array}{l}0.6819^{* * *} \\
(122.30)\end{array}$ \\
\hline income $_{t}$ & $\begin{array}{l}0.0027^{* *} \\
(2.8917)\end{array}$ & $\begin{array}{l}0.0014^{* *} \\
(2.6000)\end{array}$ & $\begin{array}{l}0.0018^{* *} \\
(2.2038)\end{array}$ & $\begin{array}{l}0.0031 * * * \\
(3.6297)\end{array}$ & $\begin{array}{l}0.0024 * * * \\
(5.1522)\end{array}$ & $\begin{array}{l}0.0027^{* * *} \\
(3.0696)\end{array}$ \\
\hline sus_tourism & $\begin{array}{l}-0.0035^{* *} \\
(2.2286)\end{array}$ & $\begin{array}{l}-0.0021^{* *} \\
(2.4743)\end{array}$ & $\begin{array}{l}-0.0018 \\
(1.1595)\end{array}$ & $\begin{array}{l}-0.0046^{* * *} \\
(3.2390)\end{array}$ & $\begin{array}{l}-0.0027 * * * \\
(3.6425)\end{array}$ & $\begin{array}{l}-0.0041^{*} \\
(2.1646)\end{array}$ \\
\hline govern $t_{t}$ & $\begin{array}{l}-0.0006 \\
(0.6084)\end{array}$ & $\begin{array}{l}-0.0021 * * * \\
(4.2978)\end{array}$ & $\begin{array}{l}-0.0019 \\
(1.3458)\end{array}$ & $\begin{array}{l}-0.0041 * \\
(2.0793)\end{array}$ & $\begin{array}{l}-0.0049 * * * \\
(4.5463)\end{array}$ & $\begin{array}{l}-0.0010 \\
(0.5960)\end{array}$ \\
\hline $\begin{array}{l}R \text {-squared } \\
S E R \\
L_{c} \text { statistics }\end{array}$ & $\begin{array}{l}0.210 \\
0.0006 \\
0.155 \\
(>0.200)\end{array}$ & $\begin{array}{l}0.764 \\
0.0003 \\
0.192 \\
(>0.200)\end{array}$ & $\begin{array}{l}0.314 \\
0.0005 \\
0.505 \\
(>0.200)\end{array}$ & $\begin{array}{l}0.337 \\
0.0005 \\
0.426 \\
(>0.200)\end{array}$ & $\begin{array}{l}0.700 \\
0.0003 \\
0.455 \\
(>0.200)\end{array}$ & $\begin{array}{l}0.199 \\
0.0006 \\
0.286 \\
(>0.200)\end{array}$ \\
\hline
\end{tabular}

Notes: Asterisks ***, **, * denote statistically significant at the 1\%, 5\% and $10 \%$ level respectively. Figures in the parentheses are t-statistics. Critical values for $L_{c}$ statistics are given in [34]. SER denotes standard error of regression.

Since the time series data is short (17 observations) we employed the DOLS and FMOLS which is a more efficient estimator that corrects for simultaneity bias and small sample bias. Interestingly, our results suggest that sustainable tourism and good governance in Malaysia do contribute in mitigating biodiversity loss measure by deforestation rates. Among the contributing factors are voice and accountability, political stability, regulatory quality, rule of law and control of corruption. 


\section{References}

1. R. Butler, Rainforest diversity - origins and implications, (2006). Retrieved 1/22/2014 from http://rainforests.mongabay.com/0301.htm.

2. R. Butler, Rainforest, (2014). Retrieved 1/22/2014 from http://rainforests.mongabay.com/

3. United Nations Environment Programme (UNEP), Environmental impacts of tourism - global level, (2014). http://www.unep.org/ Access 16/7/2014.

4. C. Christ, O. Hillel, S. Matus, J. Sweeting, Tourism and biodiversity: mapping tourism's global footprint, Washington, Conservation International and UNEP (2003)

5. L. Briguglio, M. Briguglio, Sustainable tourism in small islands: the case of Malta, Mimeo, (undated). Available at https://secure2.gov.mt/tsdu/file.aspx?f=1079

6. World Commission on Environment and Development (WCED), Our common future, London, Oxford University Press, (1987)

7. United Nations World Tourism Organization (UNWTO), Indicators of sustainable development for tourism destinations: a guidebook, Madrid, World Tourism Organization (2004)

8. K. Greenidge, N. Greenidge, Sustainable tourism development: the case of Barbados, Economic Review, 37, 1\&2, 83-125. (2011)

9. R. Butler, Tourism - an evolutionary approach, In J.G. Nelson, R.W. Butler and G. Wall (eds). Tourism and sustainable development: monitoring, planning, management, Waterloo, University of Waterloo, 27-44 (1993)

10. G. Koop, L. Tole, Is there an environmental Kuznets curve for deforestation? Journal of Development Economics, 58,231-244 (1999)

11. M. Bhattarai, M. Hammig, Institutions and the environmental Kuznets curve for deforestation: a cross country analysis for Latin America, Africa and Asia, World Development, 29, 6,995-1010 (2001)

12. N. Kishor, A. Belle, Does improved governance contribute to sustainable forest management? Journal of Sustainable Forestry, 19,55-79(2004)

13. C. Umemiya, E. Rametsteiner, F. Kraxner, Quantifying the impacts of the quality of governance on deforestation, Environmental Science \& Policy, 13,695-701 (2010)

14. D. Kaufman, A. Kraay, M. Mastruzzi, Governance matters VII: governance indicators for 19962007, World Bank Policy Research June 2008, Washington, DC, The World Bank, (2008)

15. F. Neto, A new approach to sustainable tourism development: moving beyond environmental protection, Natural Resource Forum, 3, 27, 212-222 (2003)

16. R. Nunkoo, H. Ramkissoon, Small island urban tourism: a residents' perspective, Current Issues in Tourism, 13, 1, 37-60. (2009)

17. M.V. Reddy, Sustainable tourism rapid indicators for less-developed islands: an economic perspective, International Journal of Tourism Research, 10, 557-576 (2008)

18. United Nations Environment Programme and World Tourism Organisation (UNEP-WTO), Making tourism more sustainable: a guide for policy makers, The United Nations Environment Programme, United Nations, Paris, (2005)

19. C.J. Hunter, Sustainable tourism as an adaptive paradigm, Annals of Tourism Research, 24, 4, 850-867 (1997)

20. B. Wheeller, Sustaining the ego. Journal of Sustainable Tourism, 1, 2, 232-239 (1993)

21. A. Torres-Delgado, J. Saarinen, Using indicators to assess sustainable tourism development: a review, Tourism Geographies, 16, 1, 31-47 (2014)

22. E. Yunis, Indicators to measure sustainability in tourism, Paper presented at the $7^{\text {th }}$ International Forum on Tourism Statistics, Stockholm, Sweden, (2004)

23. C. HwangSuk, E. Sirakaya, Sustainability indicators for managing community tourism, Tourism Management, 26, 3, 431-445 (2005)

24. S.F. McCool, R.N. Moisey, N.P. Nickerson, What should tourism sustain? The disconnect with industry perceptions of useful indicators, Journal of Travel Research, 40, 2,124-131 (2001) 
25. F.J. Blancas, M. Gonzalez, M. Lozano-Oyola, F. Perez, The assessment of sustainable tourism: application to Spanish coastal destinations, Ecological Indicators, 10, 2, 484-492 (2010)

26. A.F. Herrera-Ulloa, S. Lluch-Cota, H. Ramirez-Aguirre, S. Hernandez-Vazquez, A. OrtegaRubio, Sustainable performance of the tourist industry in the state of Baja California SUR, Mexico, Interciencia, 28, 5, 268-272 (2003)

27. S. Saleem, Biodiversity and economic growth, World Environment Day, June 2010, 111-118. (2010)

28. C.W.J. Granger, P. Newbold, Spurious regression in econometrics, Journal of Econometrics, 2, 111-120 (1974)

29. J.H. Stock, M. Watson, A simple estimator of cointegrating vectors in higher order integrated systems, Econometrica, 61, 783-820 (1993)

30. P.C.B. Phillips, B.E. Hansen, Statistical inference in instrumental variables regression with $I(1)$ processes, Review of Economic Studies, 57, 99-125(1990)

31. P. Narayan, S. Narayan, Determinants of demand for Fiji's exports: an empirical investigation. The Developing Economies, 62, 1,95-112 (2004)

32. D.A. Dickey, W.A. Fuller, Likelihood ratio statistics for autoregressive time series with a unit root. Econometrica, 49, 1057-1077 (1981)

33. J.G. MacKinnon, Numerical distribution functions for unit root and cointegration Tests. Journal of Applied Econometrics, 11,601-618 (1996)

34. B.E. Hansen, Tests for parameter instability in regressions with $I(1)$ processes, Journal of Business \& Economic Statistics, 10, 3,321-335(1992) 